\title{
A Central Consciousness at Work Beneath the Surface Artlessness: Narrative Strategies in "Tristram Shandy"
}

Junfang $\mathrm{Xu}^{*}$

Foreign Languages College, Jiangxi Normal University, 99 Ziyang Avenue, Nanchang 330022, China

Corresponding Author: Junfang Xu, E-mail: 1059942954@qq.com

\section{ARTICLE INFO}

Article history

Received: November 01, 2017

Accepted: January 14, 2018

Published: May 01, 2018

Volume: 7 Issue: 3

Advance access: March 2018

Conflicts of interest: None

Funding: None

\begin{abstract}
'The Life and Opinions of Tristram Shandy, Gentleman' (hereafter shortened to "Tristram Shandy") is a unique novel written by British author Laurence Sterne in the eighteenth century. While Sterne's contemporary readers may have conflicting viewpoints about the artistic value of "Tristram Shandy" because of its surface artlessness and chaos, readers today in the contexts of such twentieth-century critical theories as postmodernism, existentialism, and deconstruction, find it congenial and more intriguing. I argue that despite the apparent chaos of this novel, the author-narrator Tristram is a central consciousness that holds the whole work together. And I believe Sterne narrates his story in such a peculiar way in conformity to his own perception of the outside world. Specifically, this paper aims to explore the inventive narrative strategies employed in Sterne's "Tristram Shandy" in the three aspects of narrative structure, time-shifting technique and self-conscious narrator. Amazingly, "Tristram Shandy" presents a wholly new notion of creative writing, one that goes beyond its time, and has unbreakable connection with twentieth-century literature.
\end{abstract}

Key words: Inventiveness, Narrative Structure, Time-Shifting, Self-Conscious, Surface Artlessness, Associationism

\section{INTRODUCTION}

"Tristram Shandy" is an extraordinary novel written by British author Laurence Sterne in the eighteenth century. Generally recognized as Sterne's masterpiece and one of the world literary classics, the book has taken a relatively important position in the world literary history. It is an experimental work which enjoys considerable reputation in literary history. The book is divided into nine volumes reaching over 600 pages. The nine volumes were not published all at once, the first two volumes appeared in 1759, volume 3 and 4 came out in 1761; volume 5 and 6,1762; volume 7 and 8, 1765; volume 9,1767 . The novel mainly describes the psychic world and psychological procedure of its protagonist-Tristram Shandy. Yet, the plot narrated by the protagonist is quite insipid, without dramatic changes. Readers can only trace a disruptive chief story line: the conception, birth, naming, baptizing, circumcision, breeching of the hero as he grows up. The bulk of the novel is taken up with the theories and hobbyhorses of Tristram's father, Walter Shandy and his uncle Toby Shandy. Sterne breaks the conventions of fiction writing in the eighteenth century, and is less obsessed with the progress and growth of its protagonist than with Walter's theories and Toby's fortification. The progression of the plot is rather slow: Tristram gets born only in volume 4, and is breeched in volume 6 . The main story line is contantly sus- pended as the author-narrator starts various digresssions or comments on his own writing.

The book endures a critical history of ups and downs of its reputation since its publication. Schopenhaur considers "Tristram Shandy" one of four best novels; Foster parallels Sterne with Woolf; Nietzsche sees him as the most liberated spirit of all time. Until the rise of modern academic criticism in the early twentieth century, generations of readers centered on Sterne's indecency, his originality and his sentiment in this book. In the twentieth century, however, critics opened up various new realms of discussion, such as the form of novel, feminism, epistemology, reader response theory, etc. When it comes to the form of novel, many critics have assumed that "Tristram Shandy" is a careless book with little or no deliberate plan or order. Some recent critics, however, have discovered that behind its surface disorder, the book is planned with more care than it seems. Therefore we need to find answers to the question: what binds the interrupted story telling and various seemingly irrelevant materials together? What makes the novel unified and coherent? Critics already have different interpretation about this. William R. Siebenschuh believes that "the principles of unity that bind Tristram together are to be found beneath the paradoxes in Sterne's fundamentally coherent vision of our common human nature." Wayne C. Booth traces Sterne's use of a self-conscious 
narrator to a few comic fiction writers such as Montaigne and Swift, and argues that what Sterne learned from them was "how to employ this kind of narrator to impose unity, of however 'loose' or unconventional a kind, on seemingly disparate materials." I agree with Booth on the fact that the author-narrator Tristram is a central consciousness beneath the surface disorder. Numerous clues are planted beforehand to present the scheme, which show that the author clearly designs the apparent chaos of this novel. Yet I believe Sterne narrates his story in such a peculiar way in conformity to his own perception of the outside world. Specifically, this paper aims to explore the inventive narrative strategies employed by Sterne in "Tristram Shandy" in the three aspects of narrative structure, time-shifting technique and self-conscious narrator. The first two aspects are the parts where reading the book can be confusing and seem illogical, whereas the last part I suppose is the reason why the novel can achieve unity and wholeness.

\section{THE INVENTIVE NARRATIVE STRATEGIES EMPLOYED IN "TRISTRAM SHANDY"}

\section{The Designed Chaotic Narrative Structure}

Although “Tristram Shandy" obviously doesn't have a traditional plot, we find in it two overlapping narrative threads: the story of Shandy household including the process how Tristram is begot, born, baptized, his nose-smashing, his window-sash accident, and his breeching; and the story of uncle Toby who takes great delight in bowling-green, fortification and his amour with Widow Wadman. Set side by side with the progress of the stories are the adult narrator's opinions and observations about literary creation and his own circumstances.

The surface structure of this novel seems rather messy and disorderly. The sense of randomness and accident has permeated this work. The event at the beginning of the novel actually occurs before Tristram the narrator is born. The narration is often broken up by digressions, insertions and leaping comments. The writer's preface is in the second chapter in volume three. The eighteenth and nineteenth chapters of volume nine are blank which later are filled up in Chapter 25, and the beginning of chapter 20 is a series of mystic asterisks.

The most apparent feature of the structure of any novel is its beginning and end. Despite the continuing controversy about whether the book is ever completed, the novel presents an apparently irrelevant opening and conclusion which actually uncover a profound revelation beneath. "Tristram Shandy" breaks the tradition of beginning at the very beginning, that is, narration starts with the birth of the protagonist and carries on as he grows up. The author opens his screen at the scene of the conception of the hero with a rather comic and facetious tone. And the novel ends with a remark about a cock-and-bull story. The disrupt ending (if it can be called an ending) of this work leaves us an impression of incompleteness, which has roused a big wave of arguments as whether this book is cut short by the sudden death of the author, or the author's willful design. In spite of the surface irrelevance, the author connects the birth of Tristram at the beginning and of Obadiah's calf and the Shandy bull in the end, suggesting the similarity between them; thus the novel's major themes: impotency, time, and frustration are revealed. The character Tristram has been reduced in importance to the calf; the Shandean impotency has been extended to the family's beasts; the novel is viewed as a cock-and-bull story, the best ever told. The opening and conclusion of the book exhibit the cyclical and comic character of life itself. Although the tradition of closure of the plot is not realized, the novelist attains his own end: he builds and presents his perception of the world in which he lives.

Tristram in the monologue follows no logical order in linking up unrelated events and replaces the linear cause-effect sequence with an elaborate web-like set of patterns and themes. Readers must take great pains to catch up with his random association. For all the delusive, limiting and self-isolating character of association, it ought to be understood as one indispensable part of human cognition. In "Tristram Shandy", it has permeated the characters' everyday life and become a key cohesion point of the novel for it acts as the most important structural device that binds up all digressive episodes. For example, Mrs. Shandy associates Walter Shandy's loving-making with the winding of an old clock when Tristram is begot; uncle Toby is carried away by a casual use of military words such as "siege" during a conversation with other people; Trim can recite the fifth Commandment, if he is allowed to start at the first. The military associations help uncle Toby to pass his boring retirement and rehabilitation.

Digressions are everywhere including documents, sermons, curses, stories and so on. It seems that Sterne tries to catch the actual flow of human mind in ordinary life like a stream-of-consciousness novelist. Tristram defends his randomness in narrative by claiming the advantage of the insertion of "a good quantity of heterogeneous matter ...to keep up that just balance betwixt wisdom and folly, without which a book would not hold together a single year"(IX.xii.565). Furthermore, Sterne actually celebrates and brags about his digressive skills: “. . in all my digressions there is masterstroke of digressive skill, the merit of which has long, I fear, been overlooked by my reader...my work is digressive, and it is progressive too, - at the same time... digressions, incontestably, are the sunshine; - they are the life, the soul of reading!"(II.xxii.65) The book could have ended with any volume without losing any indispensable parts just as well as with volume 9 or could have gone on after volume 9 without eliciting any sense of redundant addition to an indefinite number of volumes. In fact, association is an important coherent point to bind the event sequences of the story together with all seemingly irrelevant materials and digressions.

Other than digressions, Sterne also includes sections that he labels as fragments. "Tristram Shandy" contains a large collection of unfinished fragments. Such as the section on whiskers in chapter 1 volume 5, Slawkenbergius' tale in the beginning of volume 4, Trim's story of the King of Bohemia and his seven castles in chapter 19 Volume 8. Sterne's interest in recovering fragments owes much to the sweeping search for antique and Gothic fragments, remains of previ- 
ous books, chips and pieces of historical relics and literary remains of past civilizations in the eighteenth century. Sterne is probably fascinated with recovering meaningful relics of the past, which can be demonstrated by Tristram's tremendous effort to look for the tomb of two lovers in volume 7 .

What is the point of including so many fragments? It is Sterne himself who designs fragments, dashes, and digressions to elicit a similar mixed response, the combination of the comic and tragic that features his work. Gradually readers have become more and more important in literary aesthetic and the comprehension of literary work should be completed with their participation. Readers are supposed to take the iniative, engage their imagination to fill in gaps and salvage the whole story line according to its temporal sequence. Sterne's novel depends on the obscurity and suggestiveness of the unfinished. The blank page, marbled page, the black page, the dashes and asterisks - all these are the author's invitation for us to participate in the comprehension and creation of the novel. An extreme instance is Tristram's invitation for his readers to draw the image of widow Wadman according to their own fancy in the space he has left blank. The episode - king of Bohemia and his Seven Castles is an obvious case of incompleteness because the narrative of the story is frequently interrupted, and finally Trim totally abandons his efforts with his inarticulateness. The story remains unfinished in the end. These careless and apparently arbitrary insets are actually indispensable components of the novel just as the major events of the story because they also present the major theme of the work. The Slawkenbergius' tale on nose which stands for male virility forms a striking contrast with the Shandean impotency, linking with Walter's relationship with Elizabeth, Uncle Toby's wound in the groin and widow Wadman, Tristram's window-sash accident and nose-smashing into a whole picture. The frustrations and impotency of the Shandean family are strengthened.

Sterne has deliberately left gaps, breaks and blanks for the readers to fill in so as to engage readers' imagination as busy as possible. "Writing, when properly managed is but a different name for conversation. As no one... would venture to talk all; - so no author, who understands the just boundaries of decorum and good breeding, would presume to think all: the truest respect which you can pay to the reader's understanding, is to halve this matter amicably, and leave him something to imagine, in his turn, as well as yourself. For my own part, I am eternally paying him compliments of this kind, and do all that lies in my power to keep his imagination as busy as my own." (II.xi.100) This frequently quoted paragraph shows clearly the narrator's intention to engage the readers' attention and participation while they are reading.

Additionally, the seemingly disorgainization agrees with the random and disruptive presence of psychological responses and activities of Tristram Shandy. Because to Sterne, the framework of the novel must conform to the true conditions of inner reality of human existence.

\section{Unique Time-shift Techniques}

In his well-known paper "The Time-Scheme of 'Tristram Shandy' and a source", Theodore Baird works out the exact time-scheme for all the events occurred in this book, and finds that there is a generally accurate time framework and that Sterne used certain source for all his dates of historical events mentioned in the work. This paper is especially instructive for readers because timeline in the book is rather complicated because of its chaotic narrative structure. Anachronies are quite common, since when the author-narrator recounts the past experiences of people like Shandy brothers, he seems to follow his own whim and nobody else's rule.

Narrative writing differs from other literary form in that the time which it takes for us to read and the time for the author to write, in both cases objective clock-time, are complicated by the time supposed to be taken up by the series of events in the story. Yet both readers and writers tend to ignore this multiple time-scheme and concentrate predominately on the story time and the chronological sequence of events in the book. The mere fact that "Tristram Shandy" is a book about writing a book decides that the narrator will be entangled in a network of complex time relations. Tristram the adult author-narrator writes his memoirs in the present, records events that occured in the past, and address readers in later moments in his imagination. The author, characters, and readers are positioned at different points in time: present, past, and future respectively. The present is where Tristram stands; readers can imagine him sitting at a chair in his study, while he recalls the past events in his family, weighs their significance and influences, and complains about the difficulties he has now in order to narrate them. In the meanwhile he is having conversation or communication with his imaginary readers, male or female, individual or group of people. This present is thick since it is impregnated with all past memories and possible dialogue with readers in the future. The past, however, shapes and intrudes into the present, thus fills the narrative with flashbacks. Tristram unveils what conventional novelists have turned away from: a true picture of human experience with extraordinary complexity, confronting directly the problem of simultaneity. A large part of difficulties he encounters during his writing stems largely from his narrative effort to bring a sense of simultaneity to a linear medium. Sterne abandons the convenient feat of narrative linearity in favor of an unmanageable but more proper form, a form analogical for experience and tries his best to suggest simultaneity in his writing.

An extreme example in "Tristram Shandy" best interprets the simultaneity of past, present and future and the actual time-dimension of literary creation, in which the various time-dimensions held by the narrator separately seem to converge. "I have got entirely out of Auxerre in this journey which I am writing now, and I am got half way out of Auxerre in that which I shall write hereafter"(VII.xxviii.467) In this sentence, present tense is used to refer to the past memory and past and future are paradoxically blended together, which successfully conveys to us the sense that the remembered past as well as the unwritten future intended are present at the same time in the creative mind when the author writes his book. The problem of simultaneity in literature, limited by print and page, is in principle insuperable. 
Try as he may, the writer can present his audience with only one thing at a time. The textural density of actual experience must be separated and laid out in a linear sequence, which conforms to the limitations of language but violates the actual empirical experience.

Sterne is aware of the difference between story time, writing time, readers' time, between objective clock-time and psychological or mental time for the individual. Sterne deliberately blends and confuses the story time with the time of writing and reading to give us a better understanding of all of them. Different time-dimensions proceed with different tempo. First of all is the time of actual occurrence, the real duration of an event. And also writing time, the usually much longer time it takes Tristram to write about it. And between the two, moving at its own medium pace, there is the time it takes Tristram's readers to read about it. In one sense the three temporal modes are separate, but in another sense they are connected, for there is one place where all these three meet: in the author's all-inclusive mind. Each consciousness is aware of one's own existence as well as the external world implying external time. Tristram falls into dilemma when he tries to equate and synchronize reality and narrative, life and its representation.

Clock-time moves forwards with necessarily even pace, while mental time at a more erratic and irregular gait. Consequently, disparities between time-dimensions frequently occur: the clock-time is indefinitely extended or shortened; as Toby and Walter descend the stair, a chapter may be written for each step. A day in Tristram's life may take a year in the writing of it. The author always complains about the delay of his writing comparing with the living time of his characters. "in short, there is no end of it;- - for my own part, I declare I have been at it these six weeks, making all the speed I possibly could,- - and am not yet born." (I.xiv.34) "I am this month one whole year older than I was this time twelve-month... and no farther than to my first day's life-_'tis demonstrative that I have three hundred and sixty-four days more life to write just now, than when I first set out; so that instead of advancing, as a common writer...I am just thrown so many volumes back... at this rate I should just live 364 times faster than I should write...the more I write, the more I shall have to write." (IV.xiii.264) He shall never overtake himself in his writing and the gap widens with astounding speed.

While story-time is halted temporarily, the characters remain available in suspended activity. Tristram or Sterne is absolutely conscious that his story with the characters in it will go on with or without him. When Walter Shandy and Toby Shandy are anxiously waiting for the birth of Tristram in volume 3 chapter 18, they feel the past two hours and ten minutes seems almost an age. They draw on Lock's theory on association of ideas to explain this phenomenon. The tempo of ideas in duration at this Tristram's birth scene is deferred by anxiety and absence of mind. The story time can be suspended and put to a stop while the narrative time continues. Waiting downstairs for Tristram's birth together with Toby, Walter Shandy wonders what other people are busy doing upstairs, "I think, replied my uncle Toby, taking his pipe from his mouth, and striking the head of it two or three times upon the nail of his left thumb, as he began his sentence, I think, says he..."(I.xxi.57) The sentence remains unfinished and the narrator digresses to the description of Uncle Toby's character. Later he picks up the moment again: "But I forget my uncle Toby, whom all this while we have left knocking the ashes out of his tobacco-pipe." (I.xxi.59) The narrator stresses that a considerable time has passed in the telling of the story with "all this while." But there has been no corresponding time in the story told. While uncle Toby's advance in time has been stopped, the writer is free to take us anywhere else, to bring before us any character. Yet once again the narrator doesn't finish the sentence and tells us about Toby's wound. Only in chapter six of volume 2 we know the rest of the whole sentence.

There is also disharmony between the readers' time and the story time. The author tries to synchronize the reader's time with that of his tale and to adapt our rhythms perfectly to his writing. When Mrs. Shandy starts her labor, Obadiah is sent for the man-midwife Dr. slop. "It is about an hour and a half's tolerable good reading since my uncle Toby rung the bell, when Obadiah was order'd to saddle a horse, and go for Dr. Slop...the man perhaps has scarce had time to get on his boots...finding it to be no more than two minutes, thirteen seconds, and three-fifth"(II.viii.95) The distance from Shandy Hall to Dr. Slop's house is about eight miles; and no horses will go that fast so as to reach the destination in more than two minutes. Yet the author assumes Obadiah should have enough time to do it.

The narrator enjoys great freedom as he goes backward and forward along the line of his story: "when a man is telling a story in the strange way I do mine, he is obliged continually to be going backwards and forwards to keep all tight together in the reader's fancy"(VI.xxxiii.419). Although Tristram the artist successfully manipulates his time-scheme, free to go backwards and forwards in story telling, and can arrange the narrative as he wishes, he is always under pressure of falling behind, he desperately tries to regain time lost, and feels anxiety when he thinks that he is running out of time. In volume 7, Tristram sets out his journey in Europe because he fears he might be outrun by Death. He fled for his life. So this journey is far from a relaxing, leisurely and easy one. Instead, Tristram hurried from one place to another, had little time to stop and enjoy the trip. The lapse of time is overwhelming, irresistible, which is true to Tristram the man as well as Tristram the artist. The brevity of life is a threat to any human being. As an artist, Tristram has huge and ambitious plans for this book: "I have forty volumes to write, and forty thousand things to say and do which no body in the world will say and do for me"(VII.i.434) His greatest fear is the sudden end of his literary career for being cut short in life.

\section{Self-conscious Narrator}

Among other things, "Tristram Shandy" is a novel about a novel, is a reflection upon itself, about its own devices, composition, and even interpretation. The first-person narrator Tristram is quite conscious about his identity as the author and the whole process of story telling. Wayne Booth argues in The Rhetoric of Fiction that Tristram acts as an unreliable 
and self-conscious narrator whose presence is actually kind of novel's chief point of coherence. We can picture him sitting in a chair in his study, writing this book, and sometimes stops the main story line and to complain about the writer's trouble and difficulties, have conversation with imaginary visiting readers.

Tristram presents in front of readers the process of composing a literary work, which usually is carried on behind the scenes. He seems to have no intention of covering up the traces of artificial ordering of the whole book. As we already know, he incorporates various digressive materials in his book and frequently jumps back and forth in time. Sometimes he even seems quite arbitrary in his writing and we see such claims as "Ask my pen,--it governs me,-- I govern not it"(VI.vi.376), or "I begin with writing the first sentence and trust Almighty God for the second"(VIII.ii.494), "A sudden impulse comes across me-I strike it - and hey for a new chapter!" (IV.x.260)

The narrator constantly comments himself as writer, and also on this book he is writing, not just as a series of events happened to the Shandy household, but also as a conscious mental product of a struggling writer. He is quite confident with his capability to maneuver the narrating process, and about the success and potential influence of this book: "As my life and opinions are likely to make some noise in the world, and if I conjecture right...be no less read than the Pilgrim's Progress itself."(I.iv.6) He keeps telling us the trouble he encounters as he narrates; how he tries desperately to synchronize writing time and story time. He aims to push the plot and the digressive narrative together ahead, only to find that it is mission impossible. All he can do is a rapid alternation and jumping back and forth to balance the two processes, keeping them go abreast. He even draws five squiggly lines which he claims that is how he tells his stories through volume 1 to 5 .

The narrator is constantly aware of his communication with his potential readers. He is having postulated conversation with them. He addresses his readers, leads them on, lures them, makes them promises, and blames them for their inattentiveness and he keeps disappointing and instructing their reading expectations. From the very beginning, he claims that he complies with readers' humor of trying to know all the secrets from the first to last, and he would just do as Horace says "ab Ovo". Tristram draws Horace as textual authority for the validity of his story telling. But later he is so confident about himself so as to claim that: "for in writing what I have set about. I shall confine myself neither to his (Horace's) rules, nor to any man's rules that ever lived."(I. iv.6)" The narrator keeps breaking narrative conventions from the very beginning. Usually the hero needs to be born before his exciting adventures can start. This book, however, begins with the conception of Tristram. Technically he can only possibly know the details afterwards from his uncle Toby. Before his birth, there insert his parents' marriage-settlement, Yorick's character and death, etc. Readers may be frustrated as they wait impatiently for the birth of the hero.

Tristram anticipates that reader will little expect what he is about to say: "'tis impossible for you to guess;- - if you could,--I should blush...I should blush as an author; inas- much as I set no small store by myself upon this very account, that my reader has never yet been able to guess at any thing... if I thought you was able to form the least judgment of probable conjecture to yourself, of what was to come in the next page,-I would tear it out of my book."(I.xxv.72) He seems certain that he will take them by surprise, and promise usually at the end of a volume that he is going to explain everything soon "The reader will be content to wait for a full explanation of these matters till the next year,- - when a series of things will be laid open which he little expects."(II. xix.143)

Tristram asks readers to have patience and tolerate his eccentricity and this odd book. Readers might be equally alienated or attracted by such a narrator. Tristram believes that if the reader is willing to follow him, their relations will change from strangers to slight acquaintance, to familiarity and finally to friendship. "Then nothing which has touched me will be thought trifling in its nature or tedious in its telling...bear with me, and let me go on, and tell my story my own way...or should sometimes put on a fool's cap with a bell to it...don't fly off,- - but rather courteously give me credit for a little more wisdom than appears upon my outside...only keep your temper." (I.vi.10) The narrator thinks that if intimacy is established between them, the interpolation in this book will not be considered irrelevant. The digressions will not just be digressions. He wishes his readers will appreciate his wisdom hidden behind comic appearance. He wants to teach as well as to amuse his readers. And from the beginning, he invites his readers to participate and collaborate in the literary creation, and tries to convey to them the mixture of joy and pathos.

We never go into the minds of such major characters as Walter Shandy and Uncle Toby. We know their thoughts only from their words or behavior. The narrator does not have free will to reveal and leap from the psychological portrayal of one character to another; all we can see is mirrored through the eyes of Tristram the narrator.

\section{CONCLUSION}

In conclusion, the book has chaotic and fragmentary surface narrative structure; the narrator skips back and forth constantly when he tells the story; and the author-narrator is fully aware of his identity as the writer and keeps engaging his imaginary readers, elicits the response intended and invites readers to participate in the writing. Tristram the narrator is a central consciousness that puts the disruptive narrative together and creates unity and wholeness.

The novel is narrated in such a peculiar way as Sterne perceived the outside world to be. Each consciousness is a microcosm; it perceives the outer world in its own way. Sterne invites all the readers to share his vision, share the way he perceives the outside world. Influenced by Lock, Lawrence Sterne stresses the subjectivity and associationism. To him, the internal psychological activities are even more important than external reality. Time is flexible and fluid, each present moment is tinged with past memories and anticipation of the future. Sterne attempts to break the confinement of linearity 
of language, and convey the readers the simultaneity of past, present, and future coexisting in consciousness.

This masterpiece of Lawrence Sterne was considered odd and eccentric by some of his contemporary critics. Yet in the context of such twentieth-century critical theories as deconstruction, existentialism, and postmodernism, its inventive techniques now have been more welcome and appreciated by readers today. "Tristram Shandy" is a rebellion against traditional art; Sterne is a representative of art innovation in English novel. Lawrence Sterne has exerted strong influence upon later writers. Many authors claim indebted to "Tristram Shandy", and Sterne's name is constantly mentioned in discussion of the twentieth-century novel. It is clear that the work is permeated with modern notion of literary creation. With the historical background of neo-classicicism domination in the eighteenth century, "Tristram Shandy" is a prophetic work beyond time, and has unbreakable connection with twentieth-century literature.

\section{REFERENCES}

Baird, Theodore."The Time-Scheme of Tristram Shandy and a source", PMLA, vol. 51, pp.803-820

Booth C, Wayne. The Rhetoric of Fiction. Chicago: The University of Chicago Press, 1983

Booth C, Wayne. "The Self-conscious Narrator in Comic Fiction before "Tristram Shandy". Ed. Melvyn New. The Life and Opionions of Tristram Shandy, Gentleman. New York: St. Martin's Press, 1992

Genette, Gerard. Narrative Discourse, trans. Jane E. Lewin, Cornell University Press, 1980

New., Melvyn ed. Critical Essays On Lawrence Sterne. New York: G. K Hall \& Co, 1998

Siebenschuh R., William. "Sterne's Paradoxical Coherence: Some Principles of Unity in Tristram Shandy", Approaches to Teaching Sterne's Tristram Shandy. Ed. Melvyn New. New York: MLA, 1989. pp.72-79

Sterne, Lawrence. The Life and Opionions of Tristram Shandy, Gentleman. London: Harper Press, 2012 